\title{
CORPORATE GOVERNANCE, EARNINGS MANAGEMENT, AND INVESTMENT OPPORTUNITY SET OF BANKING INDUSTRY IN INDONESIA
}

\author{
Agustina Ratna Dwiati, Yulian Belinda Ambarwati \\ Department of Accounting STIE Perbanas Surabaya \\ Nginden Semolo 36, Surabaya 60118, Indonesia
}

\begin{tabular}{|c|c|}
\hline & ABSTRACT \\
\hline \multirow[t]{3}{*}{$\begin{array}{l}\text { Keywords: } \\
\text { corporate } \\
\text { governance } \\
\text { mechanism, } \\
\text { earnings } \\
\text { management, } \\
\text { independent } \\
\text { commissioners, } \\
\text { investment } \\
\text { opportunity set. } \\
\text { JEL Classification: } \\
\text { G21, G32, G34 }\end{array}$} & $\begin{array}{l}\text { Earning management has become a common phenomenon that occurs within a company } \\
\text { and is difficult to avoid. Earnings management can be done because managers must obey } \\
\text { the certain rules. This happens in the banking industry because the banking industry has } \\
\text { more stringent regulations than other industries. This study aimed to examine the effect } \\
\text { of corporate governance on earnings management with investment opportunity set as } \\
\text { intervening variable. Dependent variable of this research was earnings management. } \\
\text { The independent variable of this study was corporate governance mechanism which was } \\
\text { proxy with the proportion of independent commissioners. The intervening variable of } \\
\text { this study was investment opportunity set. The samples of this study were banking com- } \\
\text { panies listed on the Indonesia Stock Exchange (BEI) in 2012-2015. The analytical method } \\
\text { used was path analysis. The results of this study indicated that corporate governance }\end{array}$ \\
\hline & $\begin{array}{l}\text { could reduce the occurrence of earnings management practices. Meanwhile, corporate } \\
\text { governance did not affect the investment opportunity set and investment opportunity set } \\
\text { did not influence the earnings management so that investment opportunity set could not } \\
\text { mediate the influence of corporate governance on earnings management. }\end{array}$ \\
\hline & ABSTRAK \\
\hline $\begin{array}{l}\text { Kata kunci: } \\
\text { mekanisme corporate } \\
\text { governance, } \\
\text { manajemen laba, } \\
\text { komisaris } \\
\text { independen, set } \\
\text { kesempatan investasi }\end{array}$ & $\begin{array}{l}\text { Manajemen laba sendiri telah menjadi suatu fenomena umum yang terjadi di dalam suatu } \\
\text { perusahaan dan sukar untuk dihindari. Manajemen laba ini bisa dilakukan karena manajer harus } \\
\text { menaati suatu aturan tertentu. Hal ini terjadi dalam industri perbankankarena industri perbankan } \\
\text { ini mempunyai regulasi yang lebih ketat dibandingkan dengan industri lain. Penelitian ini } \\
\text { bertujuan untuk menguji pengaruh corporate governance terhadap manajemen laba dengan set } \\
\text { kesempatan investasi sebagai variabel intervening. Variabel dependen penelitian ini adalah } \\
\text { manajemen laba. Variabel independen penelitian ini adalah mekanisme corporate governance } \\
\text { yang diproksikan dengan tingkatproporsi komisaris independen. Variabel intervening penelitian } \\
\text { ini adalah set kesempatan investasi. Sampel penelitian ini adalah perusahaan perbankan yang } \\
\text { terdaftar di Bursa Efek Indonesia (BEI) pada tahun 2012-2015. Metode analisis yang digunakan } \\
\text { adalah analisis jalur. Hasil penelitian ini menunjukkan bahwa corporate governance dapat } \\
\text { mengurangi terjadinya praktek manajemen laba. Sementara itu, corporate governance ternyata } \\
\text { tidak berpengaruh terhadap set kesempatan investasi dan set kesempatan investasi juga tidak } \\
\text { berpengaruh terhadap manajemen laba sehingga set kesempatan investasi tidak bisa memediasi } \\
\text { pengaruh corporate governance terhadap manajemen laba. }\end{array}$ \\
\hline
\end{tabular}

Correspondence Author:

Agustina Ratna Dwiati: Tel./Fax.+62 2178880746

E-mail: agustina@perbanas.ac.id

ISSN:2443-2687 (Online) ISSN:1410-8089 (Print) 
Managers in practice can choose the accounting policy in accordance with the desired goals. Managers may choose accounting policies that may report higher or lower profits according to their intended purpose. According to Scott (2009), this action is called earnings management.

According to agency theory, earnings management arises as the impact of agency problems namely the misalignment of interest between the owner (principal) and the manager (agent) (Beneish, 2001). As an agent, manager is morally responsible to maximize the profit of the owner (principal), but the manager also has an interest to maximize their welfare. This is most likely causing agent does not always act in the best interests of the principal (Jensen \& Meckling, 1976).

Earning management has become a common phenomenon that occurs within a company and is difficult to avoid. Earnings management can be done because managers must obey the certain rules. This happens in the banking industry because the banking industry has more stringent regulations than other industries, for example, a bank must meet the minimum CAR (Capital Adequacy Ratio) criteria. Bank Indonesia uses the financial statements as the basis in assessing the status of a bank to see whether the bank is a healthy bank or not (Wahyono et al., 2013).

Financial manipulation done by improper earnings management must be minimized to avoid the collapse of the company. Earnings management practices can be minimized with good corporate governance practices (Chen et al., 2007; Kim \& Yoon, 2008). According to Djanegara (2008) corporate governance is as a system and set of rules that govern the relationship between the various stakeholders.

Corporate governance is the mechanism developed in order to improve the company's performance and management behavior. One form of corporate governance mechanism is the presence of independent commissioners. One of the main functions of independent commissioners is to run a monitoring function that is independent to the performance of the company's management.

Researches done by Chen et al. (2007) and Kim \& Yoon (2008) indicate that an independent commissioner can reduce the likelihood of earnings management. However, researches done by Abed et al. (2012), Chekili (2012), Chan et al., (2013) and Yushita et al. (2013) indicate that an independent commissioner increases the likelihood of earnings management. In addition, the research results of Restuningdiah (2011) and Sukeecheep et al. (2013) indicate that independent commissioners do not affect earnings management.

Research on the factors affecting earnings management is interesting to be done because this earnings management practice can make big and famous companies in the world and in Indonesia collapse. In addition, the inconsistency of previous research results makes this research interesting to do.

Differences in this study suspected because of the other variables that can mediate the relationship of corporate governance and earnings management. This study will also examine whether investment opportunity set (IOS) is able to mediate the relationship between corporate governance and earnings management. IOS is an investment decision in the combination form between owned assets (assets in place) and investment choice (growth options) in the future with net present value (NPV) (Myers, 1977). The investment-based IOS proxy shows high level of corporate investment activity affecting company investment opportunities (Laksito \& Sutapa, 2011).

Several previous studies have shown that earnings management can be affected by IOS (Siahaan, 2013; Mosaee \& Pakzad, 2014). IOS itself is also influenced by corporate governance (Belghtiar \& Khan, 2013; Jannati et al., 2014). The existence of an independent board within the company is an important factor in the company growth that is proxy through IOS. 


\section{Corporate Governance, Earnings Management, and Investment Opportunity Set of Banking Industry in Indonesia Agustina Ratna Dwiati \& Yulian Belinda Ambarwati}

The purpose of this study was to examine the effect of independent commissioners in corporate governance mechanisms on earnings management, to examine the effect of independent commissioners on corporate governance mechanisms on investment opportunity set, to examine the effect of investment opportunity set on earnings management, and to examine the effect of independent commissioners on corporate governance mechanisms to earnings management through investment opportunity set.

\section{HYPOTHESES DEVELOPMENT}

\section{Corporate Governance and Earnings Management}

Corporate governance is a matter of controlling the top executive behavior of the company to protect the interests of company owners (shareholders). It means that good corporate governance can better align the interests of various parties. In addition, companies that implement corporate governance practices well should show all the relevant information to stakeholders, thereby reducing the information asymmetry (Veronica \& Bachtiar, 2005).

From the above explanation it can be concluded that good corporate governance can align the interests of principal and agent and reduce the information asymmetry. Earnings management itself occurs due to an interest conflict and information asymmetry. It means that good corporate governance can suppress earnings management.

One of the corporate governance mechanisms proven to reduce the occurrence of earnings management practices is independent commissioner. One of the main functions of the independent commissioner is to run a monitoring function that is independent to the company's management performance.

Researches done by Chen et al. (2007) and Kim \& Yoon's (2008) show that independent com- missioner can reduce the likelihood of earnings management. Researches done by Abed et al. (2012), Chekili (2012), Chan et al. (2013) and Yushita et al. (2013) state that independent commissioner can increase the likelihood of earnings management. Based on the explanation above, the proposed hypothesis is:

$\mathrm{H}_{1}$ : independent commissioner in corporate governance mechanisms affects earnings management

\section{Corporate Governance and Investment Opportunity Set}

Independent commissioner is in charge of running the monitoring functions independently on management performance. It is done to reduce agency issues that can occur between owners and management. The existence of independent commissioner is to balance the power of management in corporate management through monitoring function.

Jannati et al. (2014) states that independent commissioner is an important factor in the growth of companies where the company's growth rate can be measured through IOS. Meanwhile, Belghitar \& Khan (2013) state that independent councils have a more effective role in firms with high investment growth rates than in firms with low investment growth rates.

Based on agency theory, companies with a high proportion of independent commissioners will always think about shareholders' welfare. Therefore, independent commissioners prefer corporate investment policies that maximize shareholder wealth. In addition, firms with a high proportion of independent commissioners are less likely to make a lot of investment. This is because if the company invests, then the company will use a lot of funds (including using corporate profits) to finance its investment. As a result, shareholders do not get a share of the profits from the company 
because the company's funds are used for investment. In this case, the higher the proportion of independent commissioners is, the lower the IOS (Hsu et al., 2009) is. On that basis, the proposed hypothesis is:

$\mathrm{H}_{2}$ : independent commissioners in corporate governance mechanisms affect IOS

\section{Investment Opportunity Set and Profit Management}

Agency relationship, principal (company owner) does not have enough information about agent performance (manager). Managers have more information about self capacity, work environment, and company as a whole. Managers know well about the prospects of the company in the future because managers have more and more accurate information about the company's condition while shareholders have less information and also cannot supervise the manager's work more optimally.

Companies with high IOS contain high information asymmetries among managers and shareholders (Shanti \& Yudhanti, 2007). Managers have information about the project value in the future and their actions cannot be supervised optimally by shareholders. The absence of optimal supervision from shareholders will increase the likelihood of earnings management. This is in accordance with the research results of Mosaee \& Pakzad (2014) that conclude the existence of IOS encourages the occurrence of earnings management.

Siahaan's research (2013) proves that high IOS will improve the quality of earnings. High earnings quality indicates the low probability of earnings management. Companies with high IOS will be closely monitored by auditors, so it reduces the likelihood of managers make earnings management. On that basis, the proposed hypothesis is:
$\mathrm{H}_{3}$ : investment opportunity set affects the earnings management

\section{Corporate Governance, Investment Opportunity Set, and Earnings Management}

Independent commissioner duty is to monitor the manager performance so that managers work on behalf of the company owner. This can simultaneously reduce agency issues between owners and managers.

According to agency theory, an independent commissioner will think of the welfare of shareholders by choosing a low investment policy in order for the company to have a lot of funds that can be shared with shareholders.

A low level of investment means that the company's projects are also few. This means that the level of company information asymmetry is low and the likelihood of earnings management is also small. However, low investment can also mean that auditors' supervision becomes looser and increases the likelihood of earnings management. On that basis, the proposed hypothesis is:

$\mathrm{H}_{4}$ : independent commissioners have an influence on profit management through investment opportunity set

\section{METHOD}

The population used in this study was all banking companies listed in Indonesia Stock Exchange in the period of 2012-2015. The samples used were 104 banking companies.

The definition of operational variables and their measurements can be seen in Table 1. This study examined the direct and indirect effects of variables by using path analysis. The research model of path analysis can be seen in Figure 1. 


\section{Corporate Governance, Earnings Management, and Investment Opportunity Set of Banking Industry in Indonesia}

Agustina Ratna Dwiati \& Yulian Belinda Ambarwati

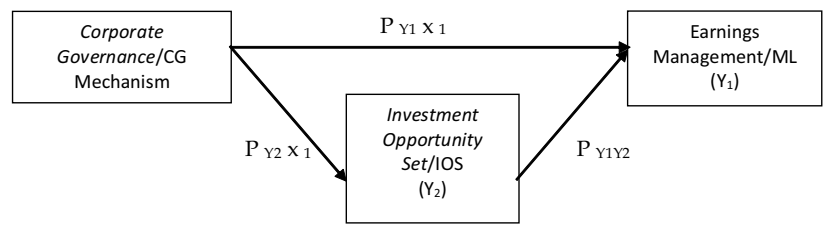

Figure 1. Path Analysis
The path analysis model consists of 2 equations:

(1) $\mathrm{ML}=$ PY1x 1 CG + P Y1Y2 IOS + e 1

(2) $\mathrm{IOS}=\mathrm{P} Y 2 X 1 \mathrm{CG}+\mathrm{e} 2$

Table 1. Definitions of Variable Operations and Measurement of Research Variables

\begin{tabular}{|c|c|c|}
\hline Variable & Proxy & Measurement \\
\hline $\begin{array}{l}\text { Earnings Management: } \\
\text { accounting policy choice by } \\
\text { managers in order to achieve } \\
\text { certain goals (Scott, 2009). }\end{array}$ & $\begin{array}{l}\text { Discretionary } \\
\text { accruals } \\
\text { (DACC) }\end{array}$ & 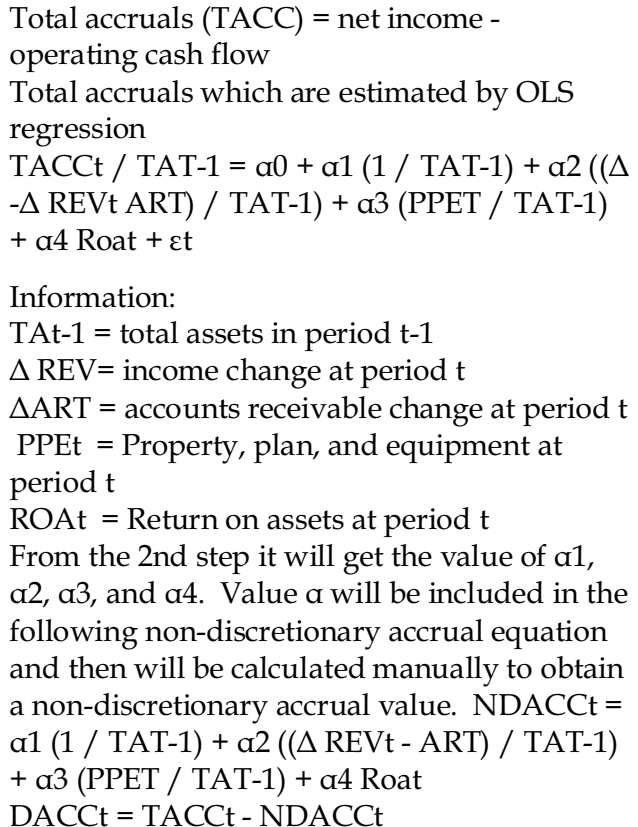 \\
\hline
\end{tabular}

Corporate Governance: system and a set of rules that govern the relationship among the various parties that have interest for corporate goals (Zarkasyi, 2008).

Investment Opportunity Set: investment decisions in the form of a combination between owned assets (assets in place) and the choice of investment (growth options) in the future with positive net present value (NPV) (Myers, 1977).
Independent Commissioner

Market to Book Value of Assets (MKTBKASS)
Percentage of independent commissioners compared to the total existing board of commissioners

[(Total assets-total equity + (circulating shares $\mathrm{x}$ closing price)) / total assets]
Reference

Kothari et al.

(2005)

Abed et al. (2012)

Adam \& Goyal (2000), Shanti \& Yudhanti (2007) 


\section{Jurnal Keuangan dan Perbankan | PERBANKAN}

Vol. 21, No. 2, April 2017: 321-330

\section{RESULTS}

\section{Descriptive statistics}

Descriptive statistics provide descriptions of data viewed from the minimum, maximum, mean, and standard deviation values. The results of descriptive statistical calculations can be seen in Table 2.

\section{Linearity Test}

Linearity test aims to see whether the model specifications used are correct or not. A good model should be linear. The linearity test could be done using Lagrange Multiplier test. If the value of $c^{2}$ count $\left(n \times R^{2}\right)<c^{2}$ table, it is concluded that the model is linear (Ghozali, 2005). Linearity test results can be seen in Table 3 .

\section{Test Autocorrelation}

Autocorrelation test aims to examine whether the linear regression model has a correlation between disruption errors in period $t$ with disruption error in period $t-1$ (previous). The way that can be done to detect the presence or absence of autocorrelation is by conducting Durbin Watson test. If the value of $d u<d<4-d u$, it can be concluded there is no autocorrelation (Ghozali, 2005). Autocorrelation test result can be seen in table 4 .

\section{Hypothesis Testing Result}

The result of hypothesis testing is done by looking at the direct and indirect effects. Table 5 shows the result of the research hypothesis testing.

Table 2. Descriptive Statistics

\begin{tabular}{lccccc}
\hline & N & Minimum & Maximum & Average & $\begin{array}{c}\text { Standard } \\
\text { Deviation }\end{array}$ \\
\hline Earnings Management & 04 & -0.2298 & 0.1725 & 0.001463 & 0.0605458 \\
Investment Opportunity Set & 04 & 0.8783 & 2.7964 & 1.087091 & 0.2499167 \\
Corporate Governance & 04 & 0.2857 & 0.8000 & 0.577362 & 0.0917462 \\
\hline
\end{tabular}

Table 3. Linearity Test Result

\begin{tabular}{lcccc}
\hline & $\mathbf{R}^{2}$ & $\begin{array}{c}\mathbf{c}^{2} \text { count } \\
\left(\mathbf{N} \times \mathbf{R}^{2)}\right.\end{array}$ & $\mathbf{c}^{2}$ table & Information \\
\hline Equation 1 & 0.000 & 0.000 & 124.342 & Linear \\
Equation 2 & 0.000 & 0.000 & 124.342 & Linear \\
\hline
\end{tabular}

Table 4. Autocorrelation Test Result

\begin{tabular}{ccccc}
\hline & Du & D & 4-du & Information \\
\hline Equation 1 & 1.583 & 2.001 & 2.417 & No autocorrelation occurs \\
Equation 2 & 1.562 & 2.222 & 2.438 & No autocorrelation occurs \\
\hline
\end{tabular}

Table 5. Hypothesis Testing Result

\begin{tabular}{cccc}
\hline Hypothesis & Direct Effect & Indirect Effect & Hypothesis Description \\
\hline $\mathrm{H}_{1}$ & $-0.220^{*}$ & - & Accepted \\
$\mathrm{H}_{2}$ & 0.034 & - & Rejected \\
$\mathrm{H}_{3}$ & 0.064 & - & Rejected \\
$\mathrm{H}_{4}$ & -0.220 & 0.002 & Rejected \\
\hline
\end{tabular}

Note: $*$ Significant at $5 \%$ 


\section{DISCUSSION}

\section{The Effect of Corporate Governance on Earnings Management}

Based on Table 5, it could be seen that corporate governance had effect on earnings management. The direct negative effect value showed that the better corporate governance would minimize the occurrence of earnings management.

Based on agency theory, interest conflict between the agent and the principal occurred because of the interests differences between agent and principal. This conflict triggered manager to do earnings management if the interest of the manager as an agent was different from the interest of the owner as the principal. A high proportion of commissioner board is predicted to hamper management to make discretionary accruals that increase profits (Fanani, 2014). It meant that independent commissioners had a negative relationship with earnings management.

The results were consistent with the studies done by Chen et al. (2007) and Kim \& Yoon (2008) indicating that an independent commissioner might reduce the likelihood of earnings management. Independent commissioners had a duty to monitor independently the management performance. This monitoring was expected that later manager could not freely work for his personal interests and they had to prefer the company so that earnings management could also be reduced.

\section{The Effect of Corporate Governance on Investment Opportunity Set}

Independent commissioner as a corporate governance mechanism was in charge of running the monitoring function independently and was expected to reduce the agency problem. Companies with a high proportion of independent commissioners would always think about shareholders' welfare. Therefore, independent commissioners preferred corporate investment policies that maximized shareholder wealth.

Based on Table 5, the existence of an independent commissioner did not affect the available investment opportunity set. There were differences in corporate governance mechanisms for banking and non-financial companies (Jannati et al., 2014). From the banking industry point of view, corporate governance concerned the way in which business and bank affairs were governed by boards of directors and senior managers (MoududUl-Huq, 2014). It meant that the independent commissioner did not regulate the business and bank affairs including in terms of investment opportunity.

\section{The Effect of Investment Opportunity Set on Earnings Management}

In the agency relationship there was asymmetry of information in which the principal (the company owner) did not have enough information about the performance of the agent (manager). Managers knew well about the prospects of the company in the future because managers had more information and accurate information about the condition of the company. In the meantime, the owner could not conduct an optimal supervision over the manager's performance. It could lead to earnings management.

Based on Table 5 it was known that the investment opportunity set did not affect the earnings management. The result of this study was in line with the research done by Shanti \& Yudhanti (2007) which indicated that the investment opportunity set did not affect earnings management. Companies that had investment opportunity did not always tend to manage their profits. It was because of the business competition so that companies avoided the management of profit to gain investor trust. 


\section{Effect of Corporate Governance on Earnings Management through Investment Opportunity Set}

According to agency theory, an independent commissioner would think of the welfare of shareholders by choosing a low investment policy so that the company had a lot of funds that could be shared with shareholders. A low level of investment meant that the company's projects were also few. It meant that the level of information asymmetry of the company was low and the likelihood of earnings management was also small. However, low investment could also mean that auditors' supervision became looser and increased the likelihood of earnings management.

Based on the table 5 it could be seen that the investment opportunity set could not mediate the effect of corporate governance on earnings management. It was because the independent commissioner could not regulate the issue of the banking business for the banking business issue was governed by director board and senior managers (Moudud-Ul-Huq, 2014). In addition, because of the business competition companies avoided doing profit management to gain investors' trust (Shanti \& Yudhanti, 2007).

\section{CONCLUSION AND SUGGESTION}

\section{Conclusion}

This study aimed to examine the effect of corporate governance on earnings management with the investment opportunity set as an intervening variable in the banking company in Indonesia. This study tested four hypotheses relating to the influence of corporate governance on earnings management with the investment opportunity set as an intervening variable in the banking company in Indonesia.

The results of this study indicate that corporate governance affect earnings management.
The existence of an independent commissioner may reduce the likelihood of earnings management. Independent commissioners are asked to do monitoring independently on management performance. This supervision can reduce the occurrence of earnings management.

Corporate governance in this case the independent commissioner does not affect the investment opportunity set. Investment opportunity set does not affect earnings management and cannot mediate the effect of corporate governance on earnings management. It is because the independent commissioner cannot regulate the banking business problem because the banking business problem is regulated by the board of directors and senior managers. It means that decisions on investment opportunities in banking companies are governed by boards of directors and senior managers. In addition, due to business competition, the companies avoid doing earnings management to gain investors' trust.

\section{Suggestion}

It is important for companies to know the factors that lead to earnings management. It is because the practice of earnings management has caused some companies in the world fall. Further researches can use corporate governance mechanisms other than independent commissioners and use companies other than banking companies.

\section{REFERENCES}

Abed, S., Al-Attar, A., \& Suwaidan, M. 2012. Corporate Governance and Earnings Management: Jordanian Evidence. International Business Research, 2(1): 216-225.

Adam, T. \& Goyal, V. K. 2000. The Investment Opportunity Set and Its Proxy Variables: Theory and Evidence. Working Paper.

Beneish, M.D. 2001. Earnings Management: A Perspective. Management Finance, 27(12): 3-17. 


\section{Corporate Governance, Earnings Management, and Investment Opportunity Set of Banking Industry in Indonesia}

Agustina Ratna Dwiati \& Yulian Belinda Ambarwati

Belghitar, Y., \& Khan, J. 2013. Governance Mechanisms, Investment Opportunity Set and SMEs Cash Holdings. Small Business Economics, 40(1): 59-72.

Chan, H., Faff, R., Khan, A., \& Mather, P. 2013. Exploring the Moderating Role of Growth Options on the Relation between Board Characteristic and Management Earnings Forecast. Corporate Governance: An International Review, 21(4): 314-333.

Chekili, S. 2012. Impact of Some Governance Mechanisms on Earnings Management: An Empirical Validation within the Tunisian Market. Journal of Business Studies Quarterly, 3(3): 95-104.

Chen, K.Y., Elder, R.J., \& Hsieh, Y. M. 2007. Corporate Governance and Earnings Management: The Implications of Corporate Governance Best-Practice Principles for Taiwanese Listed Companies. Journal of Contemporary Accounting and Economics, 3(2): 73-105.

Djanegara, M.S. 2008. Menuju Good Corporate Governance. Bogor: Kesatuan Press.

Fanani, Z. 2014. Karakteristik Perusahaan dan Corporate Governance terhadap Manajemen Laba: Studi Analisis META. Jurnal Keuangan dan Perbankan, 18(2): 181-200.

Ghozali, I. 2005. Aplikasi Analisis Multivariate dengan Program SPSS. Semarang: Badan Penerbit Universitas Diponegoro.

Hsu, C. Y., Hsiao, H. F., \& Li, C.A. 2009. Effect of Board Monitoring on Corporate Investment and Firm Performance: Taiwan Evidence. Investment Management and Financial Innovations, 6(3): 84-93.

Jannati., M.N., Mas'ud, M., \& Chalid, L. 2014. Investment Opportunity Set: Evidence from Indonesian Banking. International Journal of Business and Management Invention, 3(9): 41-46.

Jensen, M.C. \& Meckling. W. H. 1976. Theory of the Firm: Managerial Behavior, Agency Costs, and Ownership Structure. Journal of Financial Economics, 3(4): 305-360.

Kim, H. J. \& Yoon. S. S. 2008. The Impact of Corporate Governance on Earnings Management in Korea. Malaysian Accounting Review, 7(1): 43-59.
Kothari, S. P., Leone, A. J., \& Wasley, C.E. 2005. Performance Matched Discretionary Accrual Measures. Journal of Accounting and Economics, 39: 163-197.

Laksito, H. \& Sutapa. 2011. Model Prediksi Nilai Perusahaan melalui Kepemilikan Manajerial dan Set Kesempatan Investasi. Jurnal Keuangan dan Perbankan, 15(1): 49-57.

Mosaee, S., \& Pakzad, A. 2014. The Relationship between Investment Opportunities and Earnings Management of Listed Companies in Tehran Stock Exchange. MAGNT Research Report, 2: 671-684.

Myers, S.C. 1977. Determinant of Corporate Borrowing.Journal of Financial Economics, 5: 147175.

Moudud-Ul-Huq, S. 2014. Corporate Governance Practices in Banking and Non-Banking Financial Institutions of Bangladesh. IUP Journal of Corporate Governance, 13(4).

Restuningdiah, N. 2011. Komisaris Independen, Komite Audit, Internal Audit dan Risk Management Committee terhadap Manajemen Laba. Jurnal Keuangan dan Perbankan, 15 (3): 351-362.

Scott, W. R. 2009. Financial Accounting Theory. New Jersey: Prentice Hall.

Siahaan, F.O.P. 2013. The Effect of Investment Opportunity Set, the Presence of Audit Committee, the Composition of Independent Commissioner, and Managerial Ownership on Profit Quality. International Journal and Business and Social Sciences, 4(9): 210216.

Sukeecheep, S., Yaram, S.R., \& Al Farooque, O. 2013. Earnings Management and Board Characteristics in Thai Listed Companies. International Conference on Business, Economics and Accounting. Bangkok Thailand.

Shanti, J. C. \& Yudhanti, C. B. H. 2007. Pengaruh Set Kesempatan Investasi dan Leverage Finansial terhadap Manajemen Laba. Jurnal Ekonomi Bisnis dan Akuntansi, 10(3): 49-70.

Veronica, S. \& Bachtiar. Y.S. 2005. Good Corporate Governance, Information Asymmetry, and Earnings Management. Jurnal Akuntansi dan Keuangan Indonesia, 2(1): 77-106. 


\section{Jurnal Keuangan dan Perbankan | PERBANKAN}

Vol. 21, No. 2, April 2017: 321-330

Wahyono, R.E.S., Wahidahwati \& Sunaryo, A. 2013 Pengaruh Corporate Governance pada Praktek Manajemen Laba: Studi pada Industri Perbankan Indonesia. Jurnal Ilmu dan Riset Akuntansi, 1(2): 187206.
Yushita, A.N., Rahmawati, \& Triatmoko, H. 2013. Pengaruh Mekanisme Corporate Governance, Kualitas Auditor Eksternal dan Likuiditas terhadap Kualitas Laba. Jurnal Economia, 9(2): 141155.

Zarkasyi, M.W. 2008. Good Corporate Governance. Bandung: Alfabeta. 